\title{
Orthopedic Implants: Coating with TiN
}

\author{
Silvio José Gobbi*1, Vagner João Gobbi ${ }^{1}$, Gustavo Reinke ${ }^{1}$ and Ynglid Rocha ${ }^{2}$ \\ ${ }^{1}$ Faculty of Technology, Brazil
}

${ }^{2}$ Asafe, Brazil

*Corresponding author: Silvio José Gobbi, Faculty of Technology, Brazil

\begin{abstract}
ARTICLE INFO
Received: 慧 March 06, 2019

Published: 慧 March 15, 2019

Citation: Silvio José Gobbi, Vagner João Gobbi, Gustavo Reinke, Ynglid Rocha. Orthopedic Implants: Coating with TiN. Biomed J Sci \& Tech Res 16(1)2019. BJSTR. MS.ID.002786.
\end{abstract}

Keywords: Titanium Nitride; Biomaterial; Wear; Biocompatibility
ABSTRACT

There is a constant interaction between the orthopedic implant material and the biological environment of the living organism. The surface of this biomaterial plays a fundamental role in the implant / organism response. The surface is exposed to a corrosive environment and there may be a release of ions from the implant to the body and thus potential for adverse reactions such as inflammation and pain. It may also be subject to wear conditions, such as in joints, causing the release of wear particles to the surrounding tissue, which may lead to loosening of the implant. In order to improve the properties of the implants to avoid a premture intervention (revision surgery) and to increase the shelf life, superficial modifications of the implants are performed. Titanium nitride (TiN) is a coat of choice for the modification of orthopedic implants because it is biocompatible, exhibits high hardness and corrosion resistance, low coefficient of wear and friction and represents a barrier to diffusion between the implant material (substrate) and living tissue. The main objective of this work is to describe the main properties of TiN and its application in biomaterials.

\section{Introduction}

Aiming for a better quality of life of the patient the development and improvement of orthopedic implants have been extensively investigated. One of the factors that distinguish these biomaterials from any other material is the ability to be in contact with tissues of the living organism and not cause adverse reactions to it or without causing an unacceptable degree of damage to that body [1]. Some properties are required by these biomaterials. It is known that the presence of body fluids allows metal implants to release metallic ions that may accumulate in nearby tissues or be transported to other parts of the body. Corrosion is one of the major processes affecting the life and service of orthopedic appliances made of metals and alloys used as implants in the body, with the release of ions into the body [2]. Problems related to carcinogenicity, allergies, local tissue toxicity, inflammation, genotoxicity are related to metallic ions in tissues surrounding the implants. Another property of a biomaterial when deployed in places prone to wear, such as joints, is to have high wear resistance.

This property improves the stability and proper functioning of the implant device, avoiding the production of wear particles, which lead to an adverse reaction in the tissue in which they are deposited as inflammation, osteolysis, bone resorption and loosening of the implant [3-5]. As an example, commercially pure titanium (Cp Ti) and its alloys are the materials commonly used in orthopedic implants, comprising $70-80 \%$ of all materials used [6]. However, despite excellent properties such as excellent biocompatibility, density, toughness and high corrosion resistance, they have high coefficient of wear and friction, that is, they are recognized by poor tribological properties. To solve such problems superficial treatment is one of the methods used to expand the use of metallic implants. Titanium nitride coating (TiN) is used to increase corrosion resistance, surface hardness and to reduce the coefficient of wear and friction of surgical alloys of orthopedic implants $[7,8]$.

\section{Titanium Nitride - Properties}

As a ceramic coating, TiN was first introduced in the 1980s in hip and knee prostheses [9]. Titanium nitride is a ceramic material, biocompatible and extremely hard [10], in addition, it has high conductivity and electron mobility as well as a high melting point $\left(2000-4000{ }^{\circ} \mathrm{C}\right)[11,12]$, low price [13] and recognized for its 
high resistance to wear and corrosion [14-17]. Many properties of titanium nitride films have a high dependence on their composition (relationship between the nitrogen/titanium content) and their structure, which is dependent on the growth technique and the deposition parameters employed. However, some TiN coating properties are pointed out, as shown in Table 1. Its most known phases are the $\delta$-TiNx phase that has a cubic face centered structure and the $\varepsilon$-Ti2N phase with tetragonal structure, shown in the phase diagram in Figure 1 [18]. Figure 1 shows that nitrogen addition leads to an expansion of the titanium crystalline lattice to accommodate the nitrogen atoms, with its maximum concentration at $1050 \stackrel{\circ}{\circ}$ of $23 \%$ in atomic weight. For concentrations of nitrogen higher than $23 \%$ with temperatures below $1050{ }^{\circ} \mathrm{C}$, the formation of $\varepsilon$-Ti2 $\mathrm{N}$ is observed. The $\delta$-TiN phase can be obtained with concentrations of nitrogen of 40 to $55 \%$ of atomic weight [19].

Table 1: TiN property values.

\begin{tabular}{|c|c|}
\hline Property & Unity \\
\hline Density $\mathrm{g} / \mathrm{cm}^{3}[16]$ & 5.40 \\
\hline Thermal conductivity $\mathrm{W} / \mathrm{m}{ }^{\circ} \mathrm{C}[16]$ & 19.0 \\
\hline Electrical resistivity $\mu \Omega . c m[16]$ & $20 \pm 10$ \\
\hline Vickers hardness GPa [16] & $18-21$ \\
\hline Elastic modulus GPa [17] & 600 \\
\hline Thermal expansion $10-6{ }^{\circ} \mathrm{C}-1[17]$ & 9.4 \\
\hline Poisson's ratio $[17]$ & 0.25 \\
\hline
\end{tabular}

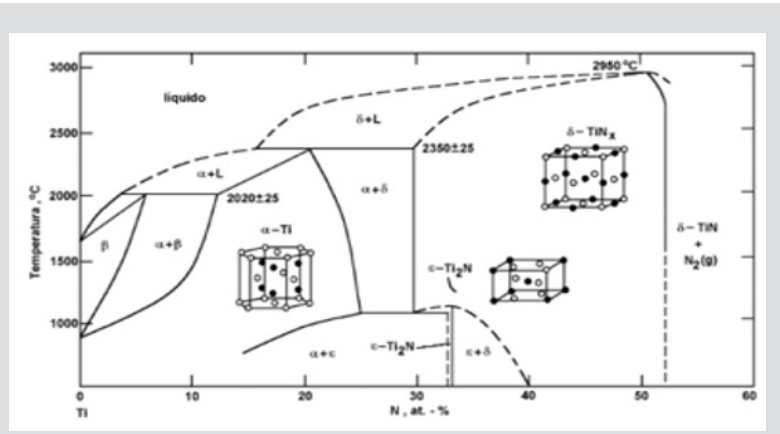

Figure 1: Phase diagram Ti - N [18].

The stoichiometry of titanium nitride also influences the visual appearance of the coatings, varying from metallic gray to reddish brown, passing through gold in stoichiometric conditions. The release of metallic ions from the substrate to the organism is reduced with the deposition of the TiN ceramic coating $[20,21]$, as a reduction of bacterial proliferation [21]. The release of metal ions from a ceramic coating is reduced due to improved corrosion resistance [22], besides the coating represents a physical barrier between the substrate and the surrounding environment. With increased wear resistance [15] there is also a reduction in the release of wear particles. Another improved property is the fatigue strength of the biomaterial $[10,14,22]$. The TiN coating is applied to titanium and its alloys, TiNi alloys, AISI 316L stainless steel, cobaltchromium, nickel-chromium, cobalt-chromium-molybdenum alloys. It is also a coating used in the coating of surgical instruments such as dental tools, files and scissors. One of the main factors for the success of the coating is the good adhesion between the same and the substrate, being determinant in the life time of the component [23]. Poor adhesion may lead to adhesive failure, i.e. delamination of the substrate coating; or a cohesive failure - fracture in the coating [17]. These failures are mainly related to the internal high residual stress of the coatings $[17,24]$. The most typical approach to increase adhesion is the deposition of a ductile metal interlayer (usually titanium) between the coating and the substrate $[17,23]$. Research also deals with the production of multilayer TiN coatings with Ti $[17,23,25]$.

\section{References}

1. Williams DF (2008) On the mechanisms of biocompatibility. Biomaterials 29(20): 2941-2953.

2. Kamachimudali U, Sridhar T M, Raj B (2003) Corrosion of bio implants. Sadhana 28(3-4): 601-637.

3. Gobbi SJ, Gobbi VJ (2018) Wear Resistance of Metallic Orthopedic Implants - Mini Review. Biomed J Sci \& Tech Res 12(3): 1-2.

4. Gobbi SJ, Gobbi VJ, Ynglid R (2019) Requirements for Selection/ Development of a Biomaterial. Biomed J Sci \& Tech Res 14(3): 1-6.

5. Geetha M, Singh AK, Asokamani R, Gogia AK (2009) Ti based biomaterials, the ultimate choice for orthopaedic implants- A review. Progress in Materials Science 54(3): 397-425.

6. Niinomi M, Nakai M, Hieda J (2012) Development of new metallic alloys for biomedical applications. Acta Biomaterialia 8(11): 3888-3903.

7. Starosvetsky D, Gotman I (2001) Corrosion behavior of titanium nitride coated Ni-Ti shape memory surgical alloy. Biomaterials 22(13): 18531859.

8. Wu WY, Chan MY, Hsu YH, Guan Zhen Chen, Shu Chuan Liao, et al. (2019) Bioapplication of TiN thin films deposited using high power impulse magnetron sputtering. Surf Coat Tech 362(25): 167-175.

9. Röstlund T, Albrektsson B, Albrektsson T, H Mc Kellop (1989) Wear of ion-implanted pure titanium against UHMWPE. Biomaterials 10(3): 176-181.

10. Duta L, Stan GE, Popa, AC, Husanu MA, Moga S, et al. (2016) Thickness Influence on In Vitro Biocompatibility of Titanium Nitride Thin Films Synthesized by Pulsed Laser Deposition. Materials 9(1): 1-19.

11. Patsalas P, Kalfagiannis N, Kassavetis S (2015) Optical properties and plasmonic performance of titanium nitride. Materials 8(6): 3128-3154.

12. Toth LE (1971) Refractory Carbides and Nitrides of Transition Elements. Academic Press.

13. Serro AP, Completo C, Colaço R, F Dos Santosd, Lobato da Silva, et al. (2009) A comparative study of titanium nitrides, TiN, TiNbN and TiCN, as coatings for biomedical applications. Surf Coat Tech 203(24): 37013707.

14. Jin S, Zhang Y, Wang Q, et al. (2013) Influence of TiN coating on the biocompatibility of medical NiTi alloy. Coll Surf Bioin 101: 343-349.

15. Kao WH, Su YL, Horng JH, Hsieh YT (2017) Improved tribological properties, electrochemical resistance and biocompatibility of AISI 316L stainless steel through duplex plasma nitriding and TiN coating treatment. J Bio App 32(1): 12-27.

16. Pierson HO (1996) Handbook of refractory carbides and nitrides properties, characteristics, processing and applications. Noyes publications, New Jersey, USA.

17. Ali R, Sebastiani M, Bemporad E (2015) Influence of Ti-TiN multilayer PVD-coatings design on residual stresses and adhesion. Mat Design 75(15): 47-56. 
18. Bell T, Bergmann HW, Lanagan J, Morton PH, Staines AM (1986) Surface Engineering of Titanium with Nitrogen. Surf Eng 2(2): 133-143.

19. Carbonari MJ, Martinelli JR (2001) Effects of hot isostatic pressure on titanium nitride films deposited by physical vapor deposition. Mat Research 4(3): 163-168.

20. Heide NS, Schultze, J W (1993) Corrosion stability of TiN prepared by ion implantation and PVD. Nucl Instrum Methods Phys Res B 80-81: 467-71.

21. Scarano A, Piattelli M, Vrespa G, Caputi S, Piattelli A (2003) Bacterial adhesion on titanium nitride-coated and uncoated implants: an in vivo human study J. Oral Implantol 29(2): 80-85.

\section{ISSN: 2574-1241}

DOI: 10.26717/BJSTR.2019.16.002786

Silvio José Gobbi. Biomed J Sci \& Tech Res

(C) This work is licensed under Creative

Submission Link: https://biomedres.us/submit-manuscript.php
22. Cizeck J, Matejicek J (2018) Medicine Meets Thermal Spray Technology: A Review of Patents. J Them spray Tech 2:1251-1279.

23. Kim GS, Lee SY, Hahn JH, Lee BY, Han JG, et al. (2003) Effects of the thickness of Ti buffer layer on the mechanical properties of TiN coatings. Surf Coat Tech 171(1-3): 83-90.

24. Oladijo OP, Venter AM, Cornish LA (2014) Correlation between residual stress and abrasive wear of WC-17Co coatings. Int JRMH Materials 44: 68-76.

25. Bemporad E, ebastiani M, Pecchio C, De Rossi S (2006) High thickness $\mathrm{Ti} / \mathrm{TiN}$ multilayer thin coatings for wear resistant applications. Surf Coat Tech 201(6): 2155-2165.

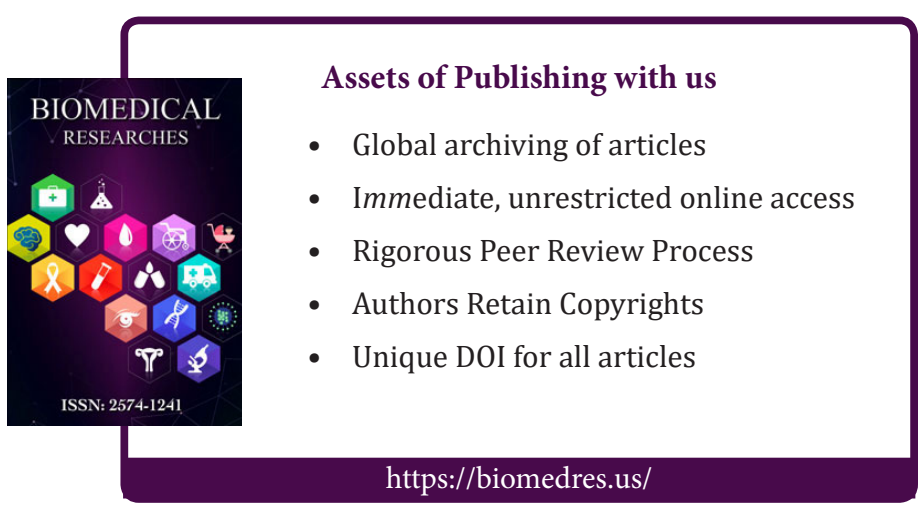

